\title{
Dampak Lingkungan Kerja Sosial dan Insentif Pada Semangat Kerja Karyawan Industri Pariwisata.
}

\author{
M.R. Nugroho ${ }^{1}$, S.H.Senen, \& E.Tarmedi \\ Universitas Pendidikan Indonesia \\ muhammad.rizal19@student.upi.edu
}

\begin{abstract}
The pupose of this paper is to find out influence social work environment and incentives against employee morale. The design of the research is a cross-sectional design. This research use descriptive and verificative approach with survey method. A total of 84 respondents were chosen as a simple random sampling. A survey questionnaire was used as research instrument to collect the data from respondents. Data analisys techniquesused in this research is multiple linier regression. The environmental impact of social work and incentives on employee morale tourism industry. The paper provides a basis to understand the issues of employ morale, incentivess and social work enviromental of tourism industrial. The difference of this study with previous research on objects that are used, the variable used, supporting the theory as well as the different references used by previous researchers
\end{abstract}

\footnotetext{
ABSTRAK

Tujuan makalah ini adalah untuk mengetahui pengaruh lingkungan kerja sosial dan insentif terhadap moral karyawan. Desain penelitian adalah desain cross-sectional. Penelitian ini menggunakan pendekatan deskriptif dan verifikatif dengan metode survei. Sebanyak 84 responden dipilih sebagai sampel acak sederhana. Survei ini digunakan sebagai instrumen penelitian untuk mengumpulkan data dari responden. Teknik analisis data yang digunakan dalam penelitian ini adalah regresi linier berganda. Dampak lingkungan dari pekerjaan sosial dan insentif pada industri pariwisata moral karyawan. Makalah ini memberikan dasar untuk memahami masalah mempekerjakan moral, insentif dan lingkungan kerja sosial pariwisata industri. Perbedaan antara penelitian ini dengan penelitian sebelumnya digunakan, variabel yang digunakan, mendukung teori serta berbagai referensi yang digunakan oleh peneliti sebelumnya
}

\author{
ARTICLE INFO: \\ Article history: \\ Received 8 July 2018 \\ Revised 8 July 2018 \\ Accepted 10 July 2018 \\ Available online 3 September \\ 2018 \\ Keywords: \\ Employee Morale, \\ Incentives, \\ Social Work \\ Environmental, \\ Tourism Industry
}

\section{Keywords:}

Moral Karyawan, Insentif, Pekerjaan Sosial Lingkungan, Industri pariwisata 


\section{PENDAHULUAN}

Pada lingkungan usaha, Sumber Daya Manusia (SDM) telah menjadi salah satu faktor yang penting dalam pencapaian tujuan perusahaan, salah satu faktor yang mempengaruhi kinerja Sumber Daya Manusia (SDM) salah satunya yaitu semangat kerja karyawan itu sendiri. Semangat kerja karyawan tentu harus menjadi bahan pertimbangan oleh perusahaan, bahwa dengan adanya semangat kerja yang baik maka perusahaan pun dapat diuntungkan dengan adanya komunikasi yang baik antar Sumber Daya Manusia (SDM), sehingga tujuan perusahaan pun akan lebih mudah untuk dicapai.

Begitu pula bagi perusahaan yang menyediakan fasilitas resort, semangat kerja karyawan menjadi hal yang sangat penting, dengan semangat kerja yang tinggi tentu karyawan akan memberikan pelayanan yang baik terhadap tamunya. Hal ini senada dengan pendapat dari Cynthia Ann LaSala (2010:4), menyebutkan bahwa karyawan yang memiliki semangat kerja yang tinggi akan memiliki tanggung jawab yang tinggi terhadap pekerjaannya.

Namun hal ini berbeda dengan keadaan di beberapa resort yang berada di sekitaran Bandung khususnya di daerah Subang. Hal ini tidak diikuti dengan kinerja yang baik, ditunjukkan dengan menurunnya semangat kerja karyawan.

Fenomena ini menjelaskan bahwa tingkat semangat kerja karyawan sangatlah penting, sesuai dengan pendapat Zendy (2011:24) mengemukakan bahwa "Semangat kerja yang tinggi akan memberikan dampak positif bagi perusahaan, sebaliknya semangat kerja yang rendah akan merugikan perusahaan seperti tingkat absensi yang tinggi, perpindahan karyawan, dan produktifitas yang rendah".

Selain dengan menurunnya tingkat kehadiran, indikator lain yang menjadi pendukung menurunnya semangat kerja karyawan diperlihatkan dengan meningkatnya pelanggaran disiplin kerja yang dilakukan oleh karyawan.

Adapun dampak lain yang disebabkan turunnya semangat kerja karyawan yaitu dengan meningkatnya presentase turnover. Terdapat beberapa faktor yang mempengaruhi semangat kerja karyawan, yaitu lingkungan kerja sosial hal ini sesuai dengan pendapat Nitisemito (2003:159) mengemukakan bahwa "Lingkungan kerja sosial yang dianggap kurang baik, artinya kurang terciptanya hubungan yang harmonis antara rekan dengan rekan, rekan dengan pimpinan bahkan pimpinan dengan pimpinan dapat menghambat semangat kerja karyawan, suasana kerja bahkan peralatan yang kurang mendukung.

Selain itu menurut Sunyoto (2012:117) dalam Lidya Agustina Siregar menyatakan bahwa, "Dengan memerhatikan lingkungan kerja sosial yang baik atau menciptakan kondisi kerja yang mampu memberikan motivasi untuk bekerja, maka akan membawa pengaruh terhadap kegairahan atau semangat kerja". (Sumber: http://repository.usu.ac.id). Hal ini diperkuat dengan pernyataan dari (Herzberg, 2003:66) dalam James Winkelhorst Saavedra "An employee's morale is closely correlated to his job and job environment and as the environment changes so does the morale".

Lingkungan kerja sosial karyawan merupakan hal yang sangat penting dalam sebuah perusahaan. Hal ini menunjukkan bahwa apa yang dilakukan perusahaan dalam membangun hubungan kerja yang baik 
memerlukan pengendalian emosional yang baik di lingkungan kerja. Namun dalam pelaksanaan programnya perusahaan masih mengalami kendala.

$$
\text { Adapun faktor lain yang }
$$
mempengaruhi semangat kerja menurut Mathis (2010:124) yaitu gaji (Kompensasi), pendidikan dan pelatihan, promosi, lingkungan kerja. Melihat kompensasi menjadi salah satu faktor yang mempengaruhi semangat kerja di suatu perusahaan, maka kompensasi mempunyai peran dalam meningkatkan semangat karyawan. Hal ini senada dengan Fajrini P. Danti (2014:4) pemberian kompensasi yang baik kepada para karyawan yang berprestasi akan berdampak pada semangat kerja yang tinggi dari para karyawan itu sendiri sehingga karyawan akan lebih bersemangat dalam bekerja.

Mengingat pentingnya semangat kerja karyawan untuk keberlangsungan perusahaan, ditemukan pemecahan permasalahan semangat kerja yaitu dengan meningkatkan bentuk lingkungan kerja dan kompensasi pada perusahaan.

\section{KAJIAN PUSTAKA}

Schultz dalam Mangkunagara (2010:107) Lingkungan kerja sosial adalah semua aspek non fisik kerja, psikologis kerja dan peraturan kerja yang dapat mempengaruhi semangat kerja dan produktivitas kerja. Menurut Sutermeister (1976:57) dalam Syamsul Hadi Senen (2009:26) mengemukakan "The major factors which establish the social condition in an organization are considered to be formal organization, informal organization or groups, leaders and supervisors and the union".

Veithzal Rivai dan Ella Jauvani (2014:355) Bentuk pembayaran yang dikaitkan dengan kinerja dan gainsharing, sebagai pembagian keuntungan bagi karyawan akibat peningkatan produktivitas atau penghematan biaya. Dimana pengguna insentif yang dibayarkan pada karyawan atas dasar produksinya melebihi standar yang ditetapkan. Sesuai pendapat Menurut Veithzal Rivai dan Ella Jauvani (2014:767) ada 8 dimensi dari insentif, yaitu: piecework, production bonus, commission, maturity curve, pay for knowledgelpay for skill compensation, nonmonetary incentive.

Moekijat (2010:135) Semangat kerja menggambarkan perasaan berhubungan dengan jiwa, semangat kelompok, kegembiraan dan kegiatan. Apabila karyawan nampak merasa senang, optimis mengenai kegiatan dan tugas serta ramah satu sama lain, maka karyawan itu dikatakan mempunyai semangat yang tinggi. Sebaliknya, apabila karyawan nampak tidak puas, lekas marah, sering sakit, suka membantah, gelisah, dan pesimis, maka reaksi ini dikatakan sebagai bukti semangat yang rendah. Indikator-indikator semangat kerja menurut Moekijat (2010:136) terdiri dari: Kegembiraan, kerjasama, kebanggaan dalam bekerja, tanggung jawab, kesetiaan

Wursanto (2009:269) mengemukakan bahwa lingkungan kerja sosial dapat memberikan dorongan dan semangat kerja yang tinggi. Handoyo Djoko W (2013:9) dalam jurnalnya lingkungan kerja sosial berpengaruh terhadap semangat kerja, semakin baik lingkungan kerja perusahaan artinya semakin baik semangat kerja karyawan yang pada akhirnya akan berdampak positif pada peningkatan kinerja karyawan. Selain itu menurut Gorda dalam jurnalnya (2004:30) mengatakan bahwa yang mempengaruhi semangat kerja karyawan salah satunya adalah lingkungan kerja dan komunikasi. Adapun menurut Nitisemito (2008:85) lingkungan kerja dalam suatu organisasi mempunyai peranan penting terhadap kelancaran pelaksanaan pekerjaan, karena lingkungan kerja yang baik bukan saja dapat memuaskan karyawan dalam 
melaksanakan tugas, tetapi berpengaruh juga dalam meningkatkan semangat kerja dan produktivitas.

Selain lingkungan kerja yang dapat mempengaruhi semangat kerja yaitu kompensasi. Mathis (2001:98) yaitu Gaji (Kompensasi), Pendidikan dan pelatihan, Promosi, Lingkungan kerja. Selain itu menurut Robbins (2003:180) faktor-faktor yang dapat mempengaruhi semangat kerja karyawan adalah kerja yang secara mental menantang, ganjaran yang pantas, kondisi kerja yang mendukung, rekan sekerja yang mendukung, kesesuaian kepribadian dengan pekerjaan. Alex S. Nitisemito (2008:107) menyatakan jelas bahwa kompensasi adalah sistem yang paling efektif sebagai pendorong yang mampu mengikat dan sekaligus menimbulkan semangat kerja. Ria Fitria (2013:15) dalam jurnalnya menyatakan adanya pengaruh lingkungan kerja sosial dan insentif secara bersama-sama berpengaruh terhadap semangat kerja karyawan.

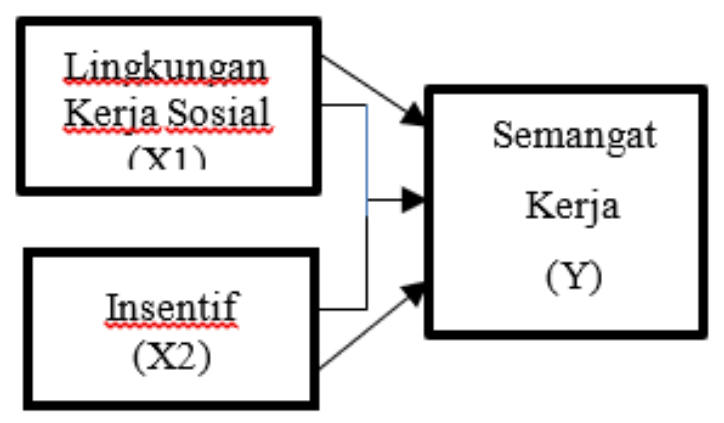

Gambar 1: Paradigma Penelitian

\section{METODEPENELITIAN}

Objek penelitian dalam penelitian ini adalah lingkungan kerja sosial, insentif dan semangat kerja. Adapun yang menjadi variabel bebas dalam penelitian ini adalah lingkungan kerja sosial $\left(\mathrm{X}_{1}\right)$, insentif $\left(\mathrm{X}_{2}\right)$ dan variabel terikatnya adalah semangat kerja (Y). Populasi dalam penelitian ini sebanyak 544 responden, karena populasi berjumlah lebih dari 100 maka digunakan teknik probability sampling, sehingga di ambil sample sebanyak 84 responden.

Penelitian ini dilakukan pada kurung waktu kurang dari satu tahun, maka metode penelitian yang digunakan adalah explanantory survey. Jenis penelitan yang digunakan adalah penelitian deskriptif dan verifikatif. Dengan demikian, maka dalam penelitian ini akan dilakukan pengujian mengenai seberapa besar pengaruh lingkungan kerja sosial dan insentif terhadap semangat kerja. Berdasarkan jenis penelitian tersebut, maka metode yang digunakan dalam penelitian ini adalah explanatory survey yang bertujuan untuk menguji hipotesis antara variabel yang satu dengan variabel yang lain.

\section{HASIL DAN PEMBAHASAN}

Untuk menguji signifikansi pengaruh lingkungan kerja sosial dan insentif terhadap semangat kerja karyawan diguakan uji $\mathrm{F}$, yaitu membandingkan antara $F_{\text {hitung }}$ dan $F_{\text {tabel. }}$ Rumus uji $\mathrm{F}$ atau uji ANOVA dijelaskan pengujian uji $\mathrm{F}$ yang dilihat dari Anova dengan tingkat probabilitas $($ Sig. $)=0,000$, dengan taraf signifikansi 0,05 yaitu $0,000 \leq 0,05$,. Artinya terdapat pengaruh yang positif antara pengaruh lingkungan kerja sosial dan insentif terhadap semangat kerja karyawan.

Peneliti juga melakukan pengujian pengaruh variabel bebas secara bersamasama terhadap variabel terikat dengan menggunakan uji F yaitu $F_{\text {hitung }}>F_{\text {tabel. }}$. Maka $F_{\text {tabel }}$ dengan 84 responden yaitu pada $\mathrm{a}=$ 0,05 adalah 3,95. Sehingga didapat 53.943>3,95, Dengan demikian dapat disimpulkan bahwa hipotesis dalam penelitian ini yaitu $\mathrm{H}_{\mathrm{o}}$ ditolak dan $\mathrm{H}_{1}$ diterima. Maka diperoleh persamaan regresi linear berganda antar komitmen organisasi 
dan motivasi kerja dengan kinerja karyawan, yaitu sebagai berikut:

$$
\mathrm{Y}=4.702+0,340 \mathrm{X} 1+0,411 \mathrm{X} 2
$$

Berdasarkan persamaan regresi linear diatas, konstanta sebesar 4.702, artinya jika tidak ada lingkungan kerja sosial dan insentif, maka besarnya kinerja karyawan sebesar 4.702. Koefisien regresi 0,340 satu satuan nilai artinya setiap terjadi peningkatan lingkungan kerja sosial akan meningkatkan semangat kerja karyawan sebesar 0,340 satu satuan nilai dan sebaliknya jika terjadi penurunan semangat kerja, lingkungan kerja sosial akan menurunkan semangat kerja karyawan sebesar 0,340 satu satuan nilai. Koefisien regresi 0,441 satu satuan nilai artinya setiap terjadi peningkatan insentif akan meningkatkan semangat kerja karyawan sebesar 0,441 satu satuan nilai dan sebaliknya jika terjadi penurunan, insentif akan menurunkan semangat kerja 0,441 satu satuan nilai.

Untuk mengetahui besarnya pengaruh variabel X1 terhadap Y, X2 terhadap Y dan pengaruh $\mathrm{X} 1$ dan $\mathrm{X} 2$ terhadap $\mathrm{Y}$, maka digunakan rumus koefisien determinasi sebagai berikut:

Keterangan:

$$
K D=r^{2} \times 100
$$

$\mathrm{r}^{2}=$ koefisien determinasi

Berikut hasil perhitungan koefisien determinasi $\mathrm{X} 1, \mathrm{X} 2$ dan $\mathrm{Y}$ :

KD X1 terhadap $\mathrm{Y}=r^{2} \times 100 \%=(0,692)^{2} \mathrm{X}$ $100=47 \%$

KD X2 terhadap $\mathrm{Y}=r^{2}$ x $100 \%=(0,696)^{2} \mathrm{x}$ $100=48 \%$

KD X1 dan X2 terhadap $\mathrm{Y}=r^{2} \times 100 \%=$ $(0,756)^{2} \times 100=57 \%$

Hasil perhitungan koefisien determinasi untuk lingkungan kerja sosial (X1) terhadap semangat kerja (Y) adalah $47 \%$, artinya semangat kerja dipengaruhi oleh lingkungan kerja sosial sebesar 47\%, sedangkan $53 \%$ dipengaruhi oleh variabel selain lingkungan kerja sosial.

Koefisien determinasi untuk insentif (X2) terhadap semangat kerja (Y) adalah $48 \%$, artinya semangat kerja dipengaruhi oleh insentif sebesar $48 \%$, sedangkan $52 \%$ dipengaruhi oleh variabel selain insentif.

Koefisien determinasi untuk lingkungan kerja sosial (X1) dan insentif (X2) terhadap semangat kerja (Y) adalah $57 \%$, artinya semangat kerja dipengaruhi $57 \%$ oleh lingkungan kerja sosial dan insentif, sedangkan $43 \%$ dipengaruhi oleh variabel lain yang tidak diteliti dalam penelitian ini. Nilai tersebut dapat dilihat juga dalam output koefisien korelasi pada lambang $r$ square

\section{KESIMPULAN DAN SARAN}

Berdasarkan pembahasan teori, hasil penelitian, dan pengujian analisis regresi linear berganda yang dilakukan mengenai pengaruh lingkungan kerja sosial dan insentif terhadap semangat kerja dapat disimpulkan lingkungan kerja sosial dan insentif mempunyai pengaruh positif terhadap semangat kerja dengan tingkat korelasi 57\%, hal ini menunjukan bahwa semakin tinggi lingkungan kerja sosial dan insentif maka akan semakin tinggi juga semangat kerja karyawan, begitu pula sebaliknya semakin rendah lingkungan kerja sosial dan insentif maka semakin rendah pula semangat kerja karyawan tersebut.

Berdasarkan hasil penelitian, maka peneliti merekomendasikan beberapa hal mengenai pelaksanaan program lingkungan kerja sosial dan insentif yang dapat meningkatkan semangat kerja karyawan,

Hasil penelitian menyatakan bahwa lingkungan kerja sosial dan insentif berpengaruh positif terhadap semangat kerja 
karyawan, maka dengan demikian penulis merekomendasikan agar perusahaan tetap menajaga, mempertahankan, mengawasi dan meningkatkan semangat kerja karyawan melalui lingkungan kerja sosial dan insentif untuk mewujudkan tujuan perusahaan 


\section{DAFTAR PUSTAKA}

A.A Anwar Prabu Mangkunagara. 2010. Prilaku dan Budaya Organisasi, Bandung: Repika Aditama

Danti, Fajarrini P. 2014, Pengaruh Kompensasi Terhadap Semangat Kerja Karyawan (Studi pada Karyawan CV. Sejahtera, Pakisaji, Malang)

Djoko, Handoyo W. 2013. Pengaruh Motivasi, Lingkungan Kerja, dan Kompensasi Terhadap Kinerja Karyawan Melalui Semangat Kerja Karyawan. Semarang.

Fitria Ria. 2013. Pengaruh Lingkungan Kerja Dan Insentif Terhadap Semangat Kerja Pegawai Pada Dana Pensiun Pt. Bpd Sumatera Barat

Frederrick Herzberg, 2003. Dasar-Dasar Manajemen. Diterjemahkan oleh Malayu S.P Hasibuan. Edisi Kedua. Jakarta : Bumi Aksara

Gorda. 2004. Manajemen Sumber Daya Manusia. Denpasar : Widya Kriya Gematama

LaSala Ann Cynthia. 2010. Creating Workplace Environments that Support Moral Courage. American Nurses Association

Mathis. L. Robert dan Jackson. H. John. 2001. Manajemen Sumber Daya Manusia,Jakarta : Buku kedua.

Mathis. L . Robert dan Jackson. H. John. 2010. Manajemen Sumber Daya
Manusia. Penterjemah Jimmy Sadeli dan Bayu Prawira Hie. Jakarta: Penerbit PT. Salemba Empat

Moekijat. 2010. Manajemen Sumber Daya Manusia. Bandung: Mandar Maju.

P. Robbins, Stephen. 2003. Organizational Behavior, Tent Edition (Perilaku Organisasi Edisi Ke Sepuluh), alih bahasa Drs. Benyamin Molan. Jakakarta : PT. Macanan Jaya Cemerlang

Rivai Veithzal \& Ella Jauvani. 2014. Manajemen Sumber Daya Manusia untuk Perusahaan. Jakarta: Raja Grafindo Persada Edisi III.

Senen, Syamsul Hadi. 2009. Pengaruh Kondisi Sosial, Kondisi Fisik, Kebutuhan Individu dan Kemampuan Kerja Terhadap Kinerja Pelayanan Serta Implikasinya Pada Kepuasan Kerja Pegawai. Bandung: Universitas Padjajaran.

Sunyoto, D. 2012. Manajemen Sumber Daya Manusia. Yogyakarta : CAPS (Center of Academy Publishing Service)

Wursanto. 2009. Dasar-dasar Ilmu Organisasi. Yogyakarta: Andi

Zendy, Pranata. 2012. Pengaruh Kompensasi, Kepemimpinan dan Motivasi Terhadap Semangat Kerja Karyawan LPD Desa Adat Kuta. Skripsi Sarjana Jurusan Manajemen pada Fakultas Ekonomi Universitas Udayana, Denpasar. 